\begin{tabular}{|c|c|c|c|c|}
\hline $\begin{array}{c}\text { Prosiding Penelitian } \\
\text { \& Pengabdian } \\
\text { Kepada Masyarakat }\end{array}$ & e ISSN : 2581-1126 & Vol 6, No: 2 & Hal: $123-180$ & Juli 2019 \\
\hline
\end{tabular}

\title{
PELAYANAN SOSIAL BAGI ANAK KORBAN KEKERASAN (SOCIAL SERVICE FOR CHILD ABUSE)
}

\author{
Nandang Mulyana ${ }^{1}$, Risna Resnawaty $^{2}$, Agus Wahyudi ${ }^{3}$ \\ 1,2,3 IImu Kesejahteraan Sosial FISIP-Universitas Padjadjaran \\ mulyananandan@yahoo.com; risnaresnawaty@unpad.ac.id; agus.wahyudi@unpad.ac.id
}

\begin{abstract}
ABSTRAK
Anak merupakan anugerah yang diberikan Tuhan kepada manusia. Akan tetapi dalam perkembangannya anak seringkali menjadi korban kekerasan. Kekerasan terhadap anak mempunyai dampak yang sangat luas dan panjang. Anak korban kekerasan akan membawa trauma selama hidupnya. Di sisi lain korban kekerasan semasa kecil mempunyai potensi untuk menjadi pelaku pada masa yang akan datang sewaktu korban tersebut telah dewasa. Trauma yang luas dan panjang ini harus mendapatkan pelayanan secara komprehensif.

Faktor penyebab terjadinya kekerasan terhadap anak adalah faktor internal dan faktor eksternal. Faktor internal adalah faktor yang berasal dari dalam keluarga. Sementara faktor eksternal adalah faktor yang terjadi diluar lingkungan keluarga. Penanganan terhadap anak korban kekerasan yang komprehensif adalah pengananan yang menyeluruh dan melibatkan berbagai pihak yang kompeten. Dengan demikian perlu adanya keterlibatan semua institusi baik itu institusi pemerintah maupun masyarakat dalam penanganan bagi anak korban kekerasan. Penanganan anak korban kekerasan juga harus memunyai payung kebijakan. Payung kebijakan ini tidak hanya bersifat nasional tetapi juga lebih spesifik dari daerah masing-masing. Pihak yang terlibat dalam penangannan anak korban kekerasan meliputi Dinas Sosial, Dinas Kesehatan, Dinas Pendidikan, Kepolisian, dan P2TP2A. Sementara dari pihak masyarakat adalah LSM yang concern terhadap anak korban kekerasan. Koordinasi natarinstitusi ini yang menjadi permasalahan.

Peningkatan koordinasi menjadi hal yang harus segera dilakukan. Koordinasi antarinstitusi ini diperlukan agar dapat saling mendukung dalam penanganan anak korban kekerasan. Hal ini diperlukan karena ada keterbatasan dari masing-masing institusi jika melakukan penanganan sendiri-sendiri.
\end{abstract}

Kata Kunci; Kekerasan terhadap anak, pelayanan komprehensif, koordinasi.

\begin{abstract}
The child is a precious gift God has given man, but in reality children often become victims of violence. Children as weak creatures are often victims of violence. Violence against children has a very large and long impact, the experiences will bring trauma during his life. On the other hand, victims of violence during childhood have the potential to become perpetrators in the future that will come when the victim has grown up. This extensive and lengthy trauma should be comprehensively also must be able to eliminate the trauma he suffered.

Caused Factors violence against children are internal factors and external factors. Internal factors are factors that come from within the family. Meanwhile external factors are factors that occur outside the family environment. Completion of children who are victims of comprehensive violence is a comprehensive and full involvement of various competent parties. Thus, the involvement of all institutions, both government institutions and the public in handling for children of victims of violence. Handling of child victims of violence must also have a policy. This policy is not only national but also more specific from each region. Parties involved in the completion of children
\end{abstract}


Prosiding Penelitian

$\&$ Pengabdian

Kepada Masyarakat e ISSN : 2581-1126

p ISSN : 2442-448X
Vol 6, No: 2
Juli 2019

victims of violence include the Department of Social Affairs, Health Office, Education Office, Police, and P2TP2A. Meanwhile the community is an NGO that concerns the child victims of violence.

This inter-institutional coordination is needed to support each other in handling child victims of violence. This is necessary because there are limitations of each institution when it comes to its own handling.

Keywords; Child abuse, comprehensive services, coordination.

\section{PENDAHULUAN}

Anak merupakan generasi penerus bagi suatu masyarakat. Kondisi ini menunjukkan bahwa anak harus mendapatkan perlakukan yang istimewa dan terbebas dari segala bentuk perlakuan yang tidak baik. Perlakuan yang istimewa bagi anak tersebut akan menjamin keberlangsungan hidp, tumbuh dan berkembang. Selain itu, anak harus mendapatkan perlakuan yang baik ini sebagai bagian dari hak anak (Apsari, 2015). Dengan demikian setiap anak berhak mendapatkan perlindungan dari setiap kekerasan dan diskriminasi. Perlindungan dari kekerasan dan dsikriminasi ini sebagai amanat dari Undang-undang Dasar Negara Republik Indonesia tahun 1945.

Perlakuan terhadap anak dalam kenyataannya tidak selalu berjalan dengan baik. Adakalanya anak mendapatkan perlakuan yang tidak baik. Data dari Komisi Nasional Perlindungan Anak (2015) memperlihatkan bahwa angka kekerasan terhadap anak di Indonesia masih tinggi. Dalam jangka waktu lima tahun (2010-2015). Pada tahun 2013 tercatat ada 2.676 kasus kekerasan terhadap anak. Dari data tersebut, $54 \%$ dari kasus kekerasan terhadap anak merupakan kejahatan seksual. Selanjutnya pada tahun 2014, tercatat 2.737 kasus kekerasan terhadap anak dengan $52 \%$ dari kasus kekerasan terhadap anak adalah kejahatan seksual. Sementara itu pada tahun 2015, Pusat Data dan Informasi (Pusdatin) Komnas Anak menerima 2.898 kasus kekerasan terhadap anak. Dari data yang dikeluarkan Pusdatin Komnas Anak tersebut, $60 \%$ dari kekerasan terhadap anak merupakan kasus kejahatan seksual. Sisanya, 40 persen lainnya adalah kekerasan fisik, penelantaran, penganiayaan, pemerkosaan, adopsi ilegal, penculikan, perdagangan anak untuk eksploitasi seksual atau ekonomi, tawuran, dan kasus narkoba. (www.Kompas.com, diakses 20 Mei2016). Kekerasan terhadap anak dapat terjadi dimanapun, tetapi $62 \%$ kekerasan terhadap anak terjadi di lingkungan terdekat yaitu dalam keluarga dan lingkungan sekolah. Sementara selebihnya $38 \%$ kekerasan terhadap anak terjadi di ruang publik (www.news.liputan6 .com diakses 20 Januari 2018).

Pada tahun 2016 Komisi Perlindungan Anak Indonesia (KPAl) (2016) mencatat, terjadi peningkatan sekitar 1.000 kasus kekerasan terhadap anak. Dari sekitar 1000 kasus tersebut, ada 136 kasus kekerasan terhadap anak yang disebabkan oleh pengaruh media sosial. Tren perkembangan teknologi menjadikan media sosial sebagai sumber utama terjadinya kekerasan saat ini, khususnya di kalangan anak-anak. Misalnya, yang terjadi pada kasus bully dan sejenisnya. Menurut data KPAl, angka kekerasan terhadap anak dalam beberapa tahun belakangan relatif menunjukan tren peningkatan. Hasil temuan KPAl dari 2011 sampai 2014, terjadi peningkatan kekerasan terhadap anak secara signifikan, yaitu tahun 2011 (2178 kasus), 2012 (3512 kasus), 2013 (4311 kasus), dan 2014 (5066 kasus).

Tingginya kekerasan terhadap anak di Indonesia, juga terjadi di Provinsi Jawa Barat. Data dari Pusat Pelayanan Terpadu Pemberdayaan Perempuan dan Anak (T2TP2A) Jawa Barat memperlihatkan bahwa selama kurun waktu 2010-2015 ada 946 kasus keekrasan terhadap anak yang ditangani. (www. Kompas.com, diakses 20 Mei 2016). Banyaknya kasus yang ditangani oleh P2TP2A Jawa Barat memperlihatkan bahwa Provinsi Jawa Barat merupakan salah satu provinsi dengan tingkat kekerasan terhadap anak yang tergolong tinggi. Data tersebut sebenarnya tidak mencerminkan banyaknya kasus kekerasan terhadap anak yang sesungguhnya. Hal ini dikarenakan data tersebut yang dilaporkan sementara masih banyak kasus kekerasan terhadap anak yang tidak dilaporkan.

Tingginya kasus kekerasan terhadap 
Prosiding Penelitian

$\&$ Pengabdian

Kepada Masyarakat e ISSN : 2581-1126

p ISSN : 2442-448X
Vol 6, No: 2
Hal: $123-180$
Juli 2019 anak harus mendapatkan perhatian dari semua elemen. Hal ini berkaitan dengan pelayanan sosial yang harus diberikan terhadap anak yang mengalami kekerasan. Pelibatan semua elemen dalam memberikan pelayanan sosial terhadap anak yang mengalami kekerasan agar pelayan sosial yang diberikan menjadi lebih komprehensif. Pelayanan terhadap anak korban kekerasan tidak hanya pelayanan fisik tetapi juga pelayanan yang lebih luas lagi. Pelayanan terhadap anak harus melibatkan semua pihak dan meliputi semua aspek dari pendidikan, kesehatan, dan aspek lainnya. Demikian juga pemberi pelayanan tidak hanya pemerintah, tetapi juga lembaga yang peduli sampai masyarakat.

Penelitian terhadap anak korban kekerasan sudah banyak dilakukan. Hal ini dikarenakan anak sebagai generasi penerus sudah seharusnya mendapatkan perlindungan dari berbagai bentui kekerasan. Beberapa penelitian tentang kekerasan terhadap anak diantaranya dilakukan oleh Praditama, Nurhadi, Budianrti (https://media.neliti.com/media/publications/ 164648-ID-kekerasan-terhadap-anak-dalamkeluarga-d.pdf diunggah tanggal, 10 Oktober 2018)) yang memperlihatkan kekerasan terhadap anak dalam keluarga. Kesimpulan yang dikemukakan dalam penelitian tersebut adalah bahwa kekerasan dalam keluarga terjadi karena adanya pewarisan dari kekerasan. Selanjutnya penelitian dari Murwati

(www.academia.edu/25534919/diunggah

tanggal 9 Oktober 2018) yang melihat kekerasan seksual terhadap anak sudah seringkali terjadi.

Sebenarnya penelitian terhadap anak korban kekerasan banyak dilakukan. Perbedaan penelitian terdahulu dengan penelitian ini lebih kepada penanganan yang diberikan kepada anak korban kekerasan. Penelitian ini mencoba untuk melihat penanganan terhadap anak korban kekerasan secara konfrehensif dengan sudut pandang pelayanan sosial yang menjadi kajian dari kesejahteraan sosial dan pekerjaan sosial.

Tujuan dari penelitian ini adalah untuk melihat faktor penyebab erjadinya kekerasan terhadap anak. Berdasarkan faktor penyebab tersebut akan berkaitan dengan kebijakan serta penanganan yang dilakukan bagi anak kerban kekerasan khususnya di Kabupaten Kuningan yang menjadi lokasi penelitian.
Penelitian ini menjadi penting karena penanganan terhadap anak korban kekerasan akan berpengaruh terhadap kehidupan anak selanjutnya bahkan setelah anak tersebut menjadi dewasa. Penanganan yang komprehensif yang diberikan kepada anak korban kekerasan akan membantu anak korban kekerasan tumbuh dan berkembang secara maksimal.

\section{TINJAUAN KONSEPTUAL Pelayanan Sosial}

Pelayanan dalam memenuhi kebutuhan dan keberfungsian sosial disebut pelayanan sosial (Moenir, 1992). Pelayanan sosial dapat juga diartikan sebagai aktivitas yang terorganisasi bertujuan membantu para anggota masyarakat untuk saling menyesuaikan diri dengan sesamanya dan dengan lingkungan sosialnya. (Kamus Istilah Kesejahteraan Sosial, 1983).

Selanjutnya Perserikatan BangsaBangsa (PBB, 1982) memberikan definisi dari pelayanan sosial sebagai suatu kegiatan yang terorganisir yang ditujukan untuk membantu tercapainya penyesuaian timbal balik diantara perorangan dan lingkungannya. Tujuan ini diwujudkan melalui penggunaan teknik-teknik dan metodemetode untuk membantu perorangan, kelompok, dan kesatuan masyarakat untuk memenuhi kebutuhan mereka, serta mampu menyelesaikan masalah penyesuaian diri mereka terhadap pola-pola kehidupan masyarakat yang selalu mengalami pergeseran dan tindakan kerja sama untuk memperbaiki kondisi-kondisi ekonomi dan sosial (dalam Soetarso: 1997). Definisi yang dikemukakan oleh PBB ini menunjukkan bahwa pelayanan sosial diberikan kepada masyarakat dalam rangka stabilisasi terhadap perubahan dan ketidakberfungsian sosial dari masyarakat akibat tidak dapat mengakses sistem sumber dan distribusi sistem sumber yang tidak merata (Boehm, 1973).

Sudiro (1998) berpendapat pelayanan sosial sebagai suatu rangkaian usaha pemberian bantuan yang ditujukan kepada manusia atau kelompok manusia dan pemecahan masalah-masalah kesejahteraan sosial untuk memenuhi berbagai kebutuhan hidup mereka, antara lain ekonomi, pendidikan, perbaikan lingkungan dan kesehatan. Kemudian Sainsbury (Fahrudin, 2012) berpendapat bahwa pelayanan sosial 
Prosiding Penelitian $\&$ Pengabdian Kepada Masyarakat e ISSN : 2581-1126

p ISSN : 2442-448X
Vol 6, No: 2
Hal: $123-180$
Juli 2019 merupakan pelayanan-pelayanan yang berkepentingan untuk memenuhi kebutuhankebutuhan sosial, meliputi antara lain kesehatan dan pendidikan, serta untuk mengurangi jenis-jenis masalah sosial tertentu khususnya masalah dan kebutuhan yang memerlukan penerimaan publik atau dapat disebut juga sebagai interaksi kepada masyarakat. Pendapat Sainsbury ini menempatkan bahwa pelayanan sosial lebih kepada memperbaiki interaksi yang terjadi sehingga masyarakat dapat menjangkau pelayanan sosia yang ada. Jangkauan terhadap pelayanan sosial yang ada dapat meredam masalah yang ada serta cepatnya permasalahan tersebut diatasi. Demikian juga pendapat Sainbury tersebut sesuai dengan klasifikasi sistem sumber yang dikemukakan oleh Mc Neil dan King (1993) yang menitikberatkan klasifikasi sistem sumber berdasarkan bidang pelayanan dan kebutuhan masyarakat serta aspek yang perlu diperhatikan dalam melihat sistem sumber.

Berbeda dengan definisi pelayanan sosial yang telah dikatakan terdahulu, Kahn (1973) mendefinisikan pelayanan sosial sebagai pelayanan yang terdiri dari programprogram yang diadakan tanpa mempertimbangkan kriteria pasar untuk menjamin suatu tingkatan dasar dalam menjamin pemenuhan kebutuhan akan kesehatan, pendidikan, dan kesejahteraan, untuk melaksanakan fungsi-fungsinya, untuk memperlancar kemampuan menjangkau dan menggunakan pelayanan-pelayanan yang telah ada, dan membantu warga masyarakat yang mengalami kesulitan dan keterbelakangan. Tekanan pendapat Kahn (1973) ini adalah pelayanan sosial diberikan tanpa mempertimbangkan kriteria pasar. Maksud dari pendapat Kahn ini bahwa pelayanan sosial harus diberikan kepada semua anggota masyarakat dengan tidak memperhitungkan untung rugi dari pelayanan sosial yang diberikan, khususnya pelayanan sosial dasar dalam bidang pendidikan, kesehatan, dan kesejahteraan (Soetarso, 1997). Semua anggota masyarakat berhak untuk mendapatkan pelayanan sosial tanpa ada kesulitan untuk membayarnya. Selain itu juga pelayanan sosial juga harus dekat dan dapat diakses oleh semua anggota masyarakat (Kahn, 1973). Selain itu pendapat Kahn juga melihat bahwa pelayanan sosial ini harus dapat diakses oleh semua masyarakat (Boehm, 1973).

Kahn (1973) juga memberikan arti yang lebih luas lagi pelayanan sosial yang dibedakan ke dalam dua arti yaitu:

1) Pelayanan sosial dalam arti luas yaitu pelayanan sosial yang mencakup fungsi pengembangan termasuk pelayanan sosial dalam bidang pendidikan, kesehatan, perumahan, tenaga kerja dan sebagainya

2) Pelayanan sosial dalam arti sempit atau disebut juga pelayanan kesejahteraan sosial mencakup program-program pertolongan dan penghidupan kepada golongan yang tidak beruntung seperti pelayanan sosial bagi anak terlantar, keluarga miskin, tuna susila, dan sebagainya.

3) Pelayanan sosial dalam arti yang luas dari Kahn ini (1973) memperlihatkan bahwa bidang pelayanan sosial ini sangat luas yang mencakup semua bidang kehidupan manusia (Mc Neil dan King, 1993). Demikian juga arti pelayanan sosial dalam arti yang sempit ini hanya diberikan kepada kelompok masyarakat yang menjadi sasaran (Mc Neil dan King, 1993).

Romanyshyn (1971) mengemukakan pendapatnya mengenai pelayanan sosial sejalan dengan yang dikemukakan oleh Kahn (1973). Romanyshyn (1971) mengatakan bahwa pelayanan sosial bukan hanya sebagai usaha memulihkan, memelihara, dan meningkatkan keberfungsian sosial individu dan keluarga, melainkan juga sebagai usaha untuk menjamin berfungsinya kolektifitas sosial, organisasi serta masyarakat. Pendapat Romanyshyn ini menunjukkan bahwa pelayanan sosial harus dapat menjamin stabilitas masyarakat sehingga dengan adanya perubahan struktur masyarakat tetap ada. Maksud dari pelayanan sosial dapat menjamin berfungsinya kolektifitas sosial masyarakat akan tercapai jika anggota masyarakat dapat memperoleh pelayanan sosial tanpa dibebani untuk pembayaran yang tinggi atau akses yang sulit sehingga pelayanan sosial sulit didapatkan (Warto, 2009, Nurdin, 1986, Soetarso, 1997). Dengan demikian tanpa mempertimbangkan kriteria pasar untuk mendapatkan pelayanan sosial (Kahn, 1971) akan mendukung jaminan keberlangsungan dari masyarakat (Romanyshyn, 1971). 
Prosiding Penelitian $\&$ Pengabdian Kepada Masyarakat e ISSN : 2581-1126

p ISSN : 2442-448X
Vol 6, No: 2
Hal: $123-180$
Juli 2019
Berdasarkan definisi-definisi tentang pelayanan sosial tersebut terlihat ada beberapa hal yang sama yaitu:

1) Pelayanan sosial merupakan pemberian bantuan yang ditujukan kepada individu, kelompok, dan masyarakat yang mempunyai masalah khususnya masalah sosial dan masalah kesejahteraan sosial.

2) Pelayanan sosial diarahkan untuk mengatasi masalah dibidang pendidikan, kesehatan, dan ekonomi serta mengatasi ketidakmampuan individu, kelompok, maupun masyarakat untuk beradaptasi dengan perubahan yang terjadi.

3) Pelayanan sosial merupakan pemberian bantuan yang diorganisasi, artinya pelayanan sosial menggunakan teknik dan metode tertentu sesuai dengan kebutuhan masyarakat dan bidang yang diberi pelayanan tadi.

Berdasarkan arti pelayanan sosial yang diberikan oleh Kahn (1973) juga mengemukakan dimensi-dimensi yang terkandung dalam pelayanan sosial yaitu:

1) Program-program mengacu kepada kegiatan-kegiatan baik yang dilakukan oleh pemerintah, swasta, maupun masyarakat

2) Tanpa mempertimbangkan kriteria pasar mengacu kepada pelayanan tersebut tidak mempertimbangkan apakah penerimanya mampu membayar atau tidak

3) Individu, keluarga, kelompok, dan masyarakat mengacu kepada sasaran dari suatu program atau kegiatan yang dilakukan

4) Kesejahteraan mengacu pada tujuan yang ingin dicapai oleh program atau kegiatan terhadap sasarannya.

Berdasarkan dimensi-dimensi yang dikemukakan oleh Kahn (1973) terlihat bahwa penyelenggara dari pelayanan sosial tersebut tidak hanya dilakukan oleh pemerintah dan swasta saja tetapi juga masyarakat. Keterlibatan masyarakat dalam pelayanan sosial ini menjadi lebih penting karena pengetahuan dan relasi yang telah terjalin dengan baik dan dapat memunculkan rasa aman bagi masyarakat yang memerlukan pelayanan sosial (Giddens, 2010). Selain itu pelayanan yang melibatkan masyarakat lebih mudah dilakukan karena sistem sumber yang paling banyak dan paling mudah diakses dan terdistribusi secara merata adalah sistem sumber informal dan kemasyarakatan (Piscus dan Minahan 1973). Suharto (2007) menilai peran pemerintah memang yang paling menonjol dalam memberikan pelayanan sosial, akan tetapi seringkali pelayanan sosial yang diberikan oleh pemerintah tidak dapat menyentuh semua masyarakat. Oleh sebab itu untuk menutupi kekurangan tersebut maka diperlukan peran swasta dalam hal ini dunia usaha dan masyarakat. Dengan demikian pemerintah, swasta, dan masyarakat harus mempunyai peran yang saling mendukung (Suharto, 2007).

Pentingnya peran pemerintah dalam memberikan pelayanan sosial kepada masyarakat dikemukakan juga oleh Fukuyama (dalam Suharto 2007). Fukuyama melihat bahwa pemerintah tidak boleh mengurangi fungsinya dalam memberikan pelayanan sosial kepada masyarakat. Akan tetapi Fukuyama (dalam Suharto 2007) menyakini bahwa peran masyarakat dalam menyediakan pelayanan sosial juga merupakan sesuatu yang penting. Hal ini disebabkan karena tidak semua pelayanan sosial yang disediakan oleh pemerintah dapat diakses oleh masyarakat serta distribusi pelayanan sosial yang tidak merata. Terlebih lagi bahwa pelayanan yang disediakan oleh pemerintah belum tentu sesuai dengan kebutuhan dan budaya yang berkembang dalam masyarakat. Akan tetapi Fukuyama tetap melihat bahwa peran pemerintah dan masyarakat harus bersinergi dalam memberikan pelayanan sosial dalam memenuhi kebutuhan dan mengatasi permasalahan yang ada.

Sejalan dengan Suharto dan Fukuyama, Prittchett (dalam Hadar 2007) juga melihat harus bersinerginya pemerintah dan masyarakat dalam memberikan pelayanan sosial. Hal ini dikarenakan adanya dua sebab, pertama, globalisasi yang ditandai dengan semakin menguatnya liberalisasi menyebabkan terjadinya kesenjangan dalam masyarakat. Akibatnya semakin banyak masyarakat yang tidak dapat mengakses pelayanan sosial yang dibtuhkan. Kedua, kebutuhan dan masalah yang dihadapi oleh masyarakat bersifat spesifik sehingga diperlukan pelayanan sosial yang spesifik juga sesuai dengan kebutuhan dan masalah yang ada.

Sejalan dengan pendapat diatas, Di Nitto (2005) mengemukakan kategori dari pelayanan sosial sebagai berikut : 
Prosiding Penelitian $\&$ Pengabdian

Kepada Masyarakat

e ISSN : 2581-1126

p ISSN : 2442-448X

Vol 6, No: 2

Hal: $123-180$

Juli 2019

1. Public Agencies yaitu badan-badan pelayanan sosial yang dibentuk oleh pemerintah.

2. Private not-Profit Corporation yaitu badan pelayanan sosial yang dibentuk oleh masyarakat tanpa bermaksud untuk mencari keuntungan.

3. Private for-Profit Corporation yaitu badan pelayanan sosial yang dibentuk sebagai badan usaha yang bertujuan untuk mencari keuntungan dari pelayanan yang diberikan.

4. Self-help Groups yaitu kelompokkelompok atau perkumpulan yang dibentuk oleh masyarakat yang merasa memiliki masalah yang sama dan menggabungkan diri di dalam perkumpulna tersebut.

5. Religion Organization yaitu badan pelayanan sosial yang diadakan oleh organisasi keagamaan.

Sejalan dengan Di Nitto (2005),

Friedlander (1974) juga mengemukakan ketegori dari pelayanan sosial sebagai berikut :

1. Public Social Services Agency yaitu badan pelayanan sosial yang dibentuk oleh pemerintah.

2. Voluntary/Private Sosial Services Agency yaitu badan pelayanan sosial yang dibentuk oleh masyarakat. Badan pelayanan sosial ini terbagi atas :

a. Sectarian yaitu badan pelayanan sosial yang diselenggarakan olehdan/atau berafiliasi kepada organisasi keagamaan.

b. Non-sectarian yaitu badan pelayanan sosial yang diselenggarakan tanpa afiliasi keagamaan baik oleh perusahaan maupun oleh perorangan dan organisasi sosial. Di Indonesia badan pelayanan sosial yang nonsectarian ini berbentuk yayasan.

\section{Model Pelayanan Sosial}

Suharto (2006) melihat bahwa pelayanan sosial juga dapat dilihat dari perspektif residual dan institusional. Perspekrif residual melihat bahwa pelayanan sosial diberikan jika kebutuhan individu tidak dapat dipenuhi dengan baik oleh lembaga yang ada dalam masyarakat seperti keluarga. Pelayanan sosial dapat dihentikan jika individu dapat berfungsi kembali. Sedangkan pespektif institusional memandang pelayanan sosial sebagai charity for unfortunates. Pelayanan sosial merupakan hak setiap warga masyarakat

Berdasarkan kelompok maupun perspektifnya, maka pelayanan sosial mencakup tiga hal yaitu:

1. Equally distributed, yaitu pelayanan sosial harus mencakup dan distribusinya menjangkau semua segmen masyarakat secara merata.

2. Accountably delivered yang menunjukkan bahwa pelayanan sosial harus mempunyai kualitas yang dapat diandalkan

3. Sustainably provided melihat bahwa pelayanan sosial harus diberikan secara melembaga dan berkelanjutan.

Cakupan pelayanan sosial tersebut mendorong terciptanya strategi yang dapat dijadikan model dalam memberikan pelayanan sosial (Suharto, 2006) yaitu :

1. Dari Residual-selekrif ke institusionaluniversal

Didasarkan kepada cakupan dari pelayanan sosial serta keberlanjutan pelayanan sosial yang diberikan maka pelayanan sosial dapat diklasifikasikan ke dalam empat model (Suharto, 2006) yaitu:

a. Model residual-universal yang melihat bahwa pelayanan sosial harus diberikan secara parsial namun pelayanan yang diberikan harus mencakup banyak penerima.

b. Model institusional-universal, melihat bahwa pelayanan sosial diselenggarakan melembaga dan berkelanjutan dengan mempunyai cakupan yang luas.

c. Model residual-selektif yang melihat pelayanan sosial harus diberikan secara parsial dan diberikan kepada kelompok terbatas serta berjangka pendek.

d. Model residual-institusional yang melihat pelayanan sosial diberikan secara melembaga dan berkelanjutan.

2. Dari problem-based approach ke right-based approach

Berbeda dengan Suharto (2006) yang mengemukakan model pelayanan sosial berdasarkan cakupan dan keberlanjutan, Spicker (20095) memberikan model yang didasarkan pada penyelenggara pelayanan 
sosial yaitu pemerintah dan masyarakat termasuk dunia usaha. Berdasarkan penyelenggara pelayanan sosial Spicker (1995) memberikan model sebagai berikut:

1. Model welfare state, yaitu model pelayanan sosial yang didominasi oleh peran pemerintah. Peran masyarakat sangat terbatas.

2. Model welfare pluralism, yaitu model pelayanan sosial dimana peran pemerintah dan masyarakat sebagai penyelenggara pelayanan sosial sama kuat dan seimbang.

3. Model welfare society, yaitu model pelayanan sosial yang penyelenggaraannya didominasi oleh masyarakat sedangkan peran pemerintah sangat terbatas.

4. Model welfare rudimentalism, yaitu model pelayanan sosial dimana peran pemerintah dan masyarakat sama-sama lemah.

Berdasarkn model yang dikemukakan oleh Spicker (1995) terlihat bahwa pelayanan sosial tidak dapat diserahkan kepada pemerintah maupun masyarakat secara penuh. Dalam penyelenggaraannya masingmasing penyeenggara baik itu pemerintah maupun masyarakat harus berperan. Dengan demikian dalam penyelenggaraan pelayanan sosia ini bersifat cross-cutting (Suharto 2007). Walaupun demikian dalam penyelenggaraan pelayanan sosial ada pihak yang berperan lebih dominan dibandingkan dengan pihak lainnya baik itu pemerintah maupun masysrakat.

\section{METODE}

Penelitian ini bermaksud untuk mengkaji penanganan terhadap anak korban kekerasana di Kabupaten Kuningan. Penelitian ini menggunakan metode deskriptif. Pendekatan yang akan digunakan dalam penelitian ini menggunakan pendekatan kualitatif. Penelitian ini akan dibagi menjadi tiga tahap yaitu tahap kajian assessment mengenai faktor penyebab dan kebijakan pelayanan terhadap anak korban kekerasan, tahap pelayanan yang diberikan terhadap anak korban kekerasan.

Data yang digunakan dalam kajian ini terbagi atas data primer dan data sekunder. Data primer didapat dari sumber data secara langsung dari lapangan serta data tersebut belum diolah. Sementara itu data sekunder yang digunakan merupakan data yang diambil setelah data tersebut diolah. Data sekunder diarahkan kepada dokumendokumen terkait dengan permasalahan dalam penanganan terhadap anak korban kekerasan. Sedangkan data primer diarahkan untuk menggali informasi secara langsung di lapangan terkait dengan faktor penyebab dan kebijakan penanganan terhadap anak korban kekerasan.

Informan yang dijadikan sumber informasi pada kajian ini meliputi beberapa pihak yang disesuaikan dengan kebutuhan kajian. Informan juga berasal dari beberapa lokasi yang berkaitan dengan permasalahan kajian. Lebih jelasnya informan yang dijadikan sumber data pada kajian ini sebagai berikut:

1. Masyarakat yang bergerak dalam penanganan terhadap anak korban kekerasan yang diharapakan akan memberikan informasi mengenai kegiatan penanganan yang dilakukan.

2. Institusi pemerintah yang meliputi dinas sosial, kepolisian, pusat kesehatan. Informasi yang digali dari institusi pemerintah ini meliputi kebijakan yang diambil oleh pemerintah dalam penangannan terhadap anak korban kekerasan.

3. Lembaga-lembaga lokal yang berkaitan dengan penanganan terhadap anak korban kekerasan.. Informasi yang digali dari lembaga-lembaga lokal ini meliputi informasi mengenai kegiatan penanganan terhadap anak korban kekerasan.

Analisis infromasi yang dilakukan merupakan proses penyusunan infromasi yang kemudian dapat ditafsirkan dengan cara menggolongkan dalam kategori tertentu. Langkah-langkah yang dilakukan dalam analisis data adalah :

1.

dalam bentuk penyeleksian, pemfokusan, simplikasi, pengabstraksian, dan transformasi data mentah yang telah diperoleh gambara yang lebih tajam tentang hasil pengamatan dan juga memudahkan peneliti untuk mencari data lain yang diperlukan.

2.

Pengujian data dengan menyusun informasi secara sistematis agar kesimpulan yang ditarik akurat

3. kesimpulan berdasarkan hasil pengujian data yang telah dilakukan

(Miles dan Huberman, 1992) 


\begin{tabular}{|c|c|c|c|c|}
\hline $\begin{array}{c}\text { Prosiding Penelitian } \\
\& \text { Pengabdian } \\
\text { Kepada Masyarakat }\end{array}$ & e ISSN : 2581-1126 & Vol 6, No: 2 & Hal: $123-180$ & Juli 2019 \\
\hline
\end{tabular}

Penelitian mengenai penanganan terhadap anak korban kekerasan ini berlokasi di Kabupaten Kuningan. Alasan pemilihan lokasi penelitian ini dikarenakan Kabupaten Indramayu dengan berbagai permasalahan dapat mendorong pihak tertentu untuk melakukan kekerasan kepada anak sebagai pihak yang paling lemah. Selain itu juga Kabupaten Indramayu mempunyai kebijakan bagi penanganan terhadap anak korban kekerasan.

\section{HASIL DAN PEMBAHASAN}

\section{Sekilas Kabupaten Kuningan}

Kabupaten Kuningan merupakan salah satu kabupaten yang ada di Provinsi Jawa Barat. Kabupaten Kuningan secara geografis terletak antara 06 $47^{\prime}$ - 07 ${ }^{\circ} 12^{\prime}$ Lintang Selatan dan 108 $23^{\prime}$ - 108 ${ }^{\circ} 7^{\prime}$ Bujur Timur. Kabupaten Kuningan berbatasan sebelah utara, berbatasan dengan Kabupaten Cirebon, sebelah timur berbatasan dengan Kabupaten Brebes Provinsi Jawa Tengah. Sementara sebelah selatan, berbatasan dengan Kabupaten Ciamis dan sebelah barat berbatasan dengan Kabupaten Majalengka.

Luas Wilayah Kabupaten Kuningan adalah 1.195,71 km ${ }^{2}$ atau sekitar sekitar $2,52 \%$ dari luas wilayah Provinsi Jawa Barat $\left( \pm 44.357,00 \mathrm{~km}^{2}\right)$. Sebagian besar wilayah merupakan lereng bukit dan pegunungan dengan rata-rata ketinggian di bagian utara dan barat sekitar $700 \mathrm{~m}$ serta sebelah selatan dan timur antara $120 \mathrm{~s} / \mathrm{d} 222 \mathrm{~m}$. Dengan topografi seperti demikian Kabupaten Kuningan mempunyai potensi yang sangat besar di bidang pertanian, baik tanaman padi/palawija maupun tanaman hortikultura yaitu tanaman sayuran, buahbuahan dan sebagainya. Selama lima tahun terakhir di Kabupaten Kuningan tidak terjadi penambahan wilayah administrasi baik kecamatan maupun desa/kelurahan. Jumlah kecamatan yang ada yaitu sebanyak 32 kecamatan serta terdiri dari 361 desa dan 15 kelurahan. Tabel berikut memperlihatkan kecamatan dan luas wilayah di Kabupaten Kuningan sebagai berikut:

Tabel 1

\section{Luas Wilayah Menurut Kecamatan di Kabupaten Kuningan}

\begin{tabular}{|l|r|r|}
\hline \multicolumn{1}{|c|}{ Kecamatan } & Luas $\mathbf{( k m}^{\mathbf{2}} \mathbf{)}$ & Persentase \\
\hline 01. Darma & 51,71 & 4,33 \\
\hline 02. Kadugede & 18,22 & 1,52 \\
\hline 03. Nusaherang & 18,21 & 1,52 \\
\hline 04. Ciniru & 49,88 & 4,17 \\
\hline 05. Hantara & 35,49 & 2,97 \\
\hline 06. Selajambe & 36,73 & 3,07 \\
\hline 07. Subang & 47,58 & 3,98 \\
\hline 08. Cilebak & 42,50 & 3,55 \\
\hline 09. Ciwaru & 52,17 & 4,36 \\
\hline 10. Karangkancana & 65,35 & 5,46 \\
\hline 11. Cibingbin & 70,91 & 5,93 \\
\hline 12. Cibeureum & 47,09 & 3,94 \\
\hline 13. Luragung & 47,74 & 3,99 \\
\hline 14. Cimahi & 38,77 & 3,24 \\
\hline 15. Cidahu & 42,22 & 3,53 \\
\hline 16. Kalimanggis & 20,90 & 1,75 \\
\hline 17. Ciawigebang & 60,61 & 5,07 \\
\hline 18. Cipicung & 21,37 & 1,79 \\
\hline 19. Lebakwangi & 19,81 & 1,66 \\
\hline 20. Maleber & 57,48 & 4,81 \\
\hline 21. Garawangi & 29,96 & 2,51 \\
\hline 22. Sindangagung & 13,12 & 1,10 \\
\hline 23. Kuningan & 30,06 & 2,51 \\
\hline 24. Cigugur & 35,37 & 2,96 \\
\hline 25. Kramatmulya & 16,99 & 1,42 \\
\hline 26. Jalaksana & 37,09 & 3,10 \\
\hline 27. Japara & 27,19 & 2,27 \\
\hline 28. Cilimus & 35,41 & 2,96 \\
\hline
\end{tabular}




\begin{tabular}{|c|c|c|c|c|}
\hline $\begin{array}{c}\text { Prosiding Penelitian } \\
\& \text { Pengabdian }\end{array}$ & e ISSN : 2581-1126 & Vol 6, No: 2 & Hal: $123-180$ & Juli 2019 \\
Kepada Masyarakat & p ISSN : 2442-448X & . & \\
\hline
\end{tabular}

\begin{tabular}{|l|r|r|}
\hline 29. Cigandamekar & 22,31 & 1,87 \\
\hline 30. Mandirancan & 35,03 & 2,93 \\
\hline 31. Pancalang & 19,24 & 1,61 \\
\hline 32. Pasawahan & 49,20 & 4,11 \\
\hline $\begin{array}{l}\text { Kabupaten } \\
\text { Kuningan }\end{array}$ & $\mathbf{1 ~ 1 9 5 , 7 1}$ & $\mathbf{1 0 0 , 0 0}$ \\
\hline
\end{tabular}

Sumber : BPS Kabupaten Kuningan

Berdasarkan tabel 1. Terlihat bahwa kecamatan yang mimiliki luas paling besar adalah Kecamatan Cibingbin 70,91 $\mathrm{KM}^{2}$ dan

luas wilayah paling kecil berada di kecamatan Sindangagung sebesar 13,12 KM2. Sedangkan dilihar dari iklim, Kabupaten Kuningan termasuk ke dalam wilayah beriklim tropis. Rata- rata suhu udara sepanjang tahun rata-rata $29,08^{\circ} \mathrm{C}$. suhu terendah sebesar $23^{\circ} \mathrm{C}$, sedangkan suhu tertinggi mencapai $31^{\circ} \mathrm{C}$. Curah hujan tertinggi di Kabupaten Kuningan rata-rata $382,92 \mathrm{~mm}$. curah hujan tertinggi terjadi pada bulan Januari. Sementara pada bulan Agustus dan Oktober curah hujan terrendah.

Tabel 2 memperlihatkan jumlah penduduk dan rasio jenis kelamin di Kabupaten Kuningan sebagai berikut:

Tabel 2

Jumlah Penduduk dan Rasio Jenis Kelamin Menurut Kecamatan di Kabupaten Kuningan

\begin{tabular}{|c|c|c|c|c|c|c|}
\hline \multirow[t]{2}{*}{ No } & \multirow[t]{2}{*}{ Kecamatan } & \multicolumn{3}{|c|}{ Jumlah penduduk (ribu) } & \multicolumn{2}{|c|}{$\begin{array}{l}\text { Laju pertumbuhan } \\
\text { penduduk pertahun (\%) }\end{array}$} \\
\hline & & 2010 & 2014 & 2015 & $2010-2015$ & $2014-2015$ \\
\hline 1 & Darma & 44635 & 45732 & 46008 & 3,08 & 0,60 \\
\hline 2 & Kadugede & 23855 & 24441 & 24589 & 3,08 & 0,61 \\
\hline 3 & Nusaherang & 17313 & 17739 & 17846 & 3,08 & 0,60 \\
\hline 4 & Ciniru & 17488 & 17918 & 18027 & 3,08 & 0,61 \\
\hline 5 & Hantara & 12686 & 12998 & 13077 & 3,08 & 0,61 \\
\hline 6 & Lajambe & 12894 & 13211 & 13291 & 3,08 & 0,61 \\
\hline 7 & Subang & 15876 & 16266 & 16364 & 3,07 & 0,60 \\
\hline 8 & Cilebak & 10720 & 10983 & 11050 & 3,08 & 0,61 \\
\hline 9 & Ciwaru & 29812 & 30545 & 30729 & 3,08 & 0,60 \\
\hline 10 & Karangkancana & 20346 & 20846 & 20972 & 3,08 & 0,60 \\
\hline 11 & Cibingbin & 36091 & 36979 & 37202 & 3,08 & 0,60 \\
\hline 12 & Cibeureum & 18439 & 18892 & 19006 & 3,08 & 0,60 \\
\hline 13 & Luragung & 36914 & 37822 & 38050 & 3,08 & 0,60 \\
\hline 14 & Cimahi & 35189 & 36054 & 36271 & 3,07 & 0,60 \\
\hline 15 & Cidahu & 39356 & 40324 & 40567 & 3,08 & 0,60 \\
\hline 16 & Kalimanggis & 22992 & 23557 & 23699 & 3,07 & 0,60 \\
\hline 17 & Ciawigebang & 79848 & 81811 & 82305 & 3,08 & 0,60 \\
\hline 18 & Cipicung & 25717 & 26349 & 26508 & 3,08 & 0,60 \\
\hline 19 & Lebakwangi & 38840 & 39795 & 40035 & 3,08 & 0,60 \\
\hline 20 & Maleber & 40319 & 41310 & 41560 & 3,08 & 0,61 \\
\hline 21 & Garawangi & 38828 & 39783 & 40023 & 3,08 & 0,60 \\
\hline 22 & Sindangagung & 33676 & 34504 & 34712 & 3,08 & 0,60 \\
\hline 23 & Kuningan & 90339 & 92562 & 93121 & 3,08 & 0,60 \\
\hline 24 & Cigugur & 41909 & 42939 & 43199 & 3,08 & 0,61 \\
\hline 25 & Kramatmulya & 45469 & 46587 & 46869 & 3,08 & 0,61 \\
\hline 26 & Jalaksana & 42731 & 43782 & 44046 & 3,08 & 0,60 \\
\hline 27 & Japara & 18143 & 18589 & 18701 & 3,08 & 0,60 \\
\hline 28 & Cilimus & 44102 & 45186 & 45459 & 3,08 & 0,60 \\
\hline 29 & Cigandamekar & 27221 & 27891 & 28059 & 3,08 & 0,60 \\
\hline 30 & Mandirancan & 20163 & 20659 & 20783 & 3,07 & 0,60 \\
\hline
\end{tabular}




\begin{tabular}{|c|c|c|c|c|}
\hline $\begin{array}{c}\text { Prosiding Penelitian } \\
\& \text { Pengabdian } \\
\text { Kepada Masyarakat }\end{array}$ & e ISSN : 2581-1126 & Vol 6, No: 2 & Hal: $123-180$ & Juli 2019 \\
\hline
\end{tabular}

\begin{tabular}{|c|c|c|c|c|c|c|}
\hline 31 & Pancalang & 21230 & 21752 & 21883 & 3,08 & 0,60 \\
\hline 32 & Pasawahan & 20767 & 21278 & 21406 & 3,08 & 0,60 \\
\hline \multicolumn{2}{|c|}{ Kabupaten Kuningan } & 1.023 .90 & 1.049 .084 & 1.055 .417 & 3,08 & 0,60 \\
& 8 & & & & \\
\hline
\end{tabular}

Sumber : Data BPS Kabupaten Kuningan

Berdasarkan dua tabel diatas terlihat bahwa kepadatan penduduk paling banyak di Kecamatan Kuningan dengan kepadatan 3.098 jiwa per $\mathrm{km}^{2}$. Sementara Kecamatan Cilebak merupakan kecamatan dengan kepadatan penduduk terendah yaitu 260 jiwa per $\mathrm{km}^{2}$. Kondisi ini dapat dipahami karena Kecamatan Kuningan merupakan pusat pemerintahan dan kegiatan ekonomi di Kabupaten Kuningan. Sedangkan kecamatan dengan kepadatan terendah adalah Kecamatan Cilebak, dengan kepadatan per km2 hanya 260 jiwa, Sementara dilihat dari komposisi berdasarkan jenis kelamin, penduduk laki-laki tercatat sebanyak 530.575 jiwa dan penduduk perempuan sebanyak 524.842 jiwa, dengan sex ratio sebesar 1,01.

Sementara itu penduduk Kabupaten Kuningan didasarkan pada komposisi umur termasuk ke dalam expansive atau piramida penduduk muda. Kondisi ini menunjukkan bahwa penduduk Kabupaten Kuningan didomonasi oleh penduduk dengan usia muda. Hal tersebut tentunya perlu mendapat perhatian karena menyangkut penyediaan sarana prasarana kesehatan dan pendidikan dasar serta penyediaan lapangan kerja bagi penduduk yang masuk kelompok angkatan kerja. Berikut ini jumlah pendudukm menurut kelompok umur dan jenis kelamin di Kabupaten Kuningan sebagai berikut:

Tabel 3

Jumlah Penduduk Menurut Kelompok Umur dan Jenis Kelamin di Kabupaten Kuningan

\begin{tabular}{|c|c|c|c|}
\hline \multirow{2}{*}{$\begin{array}{c}\text { Kelompok } \\
\text { umur }\end{array}$} & \multicolumn{2}{|c|}{ Jenis kelamin } & \multirow{2}{*}{ Total } \\
\cline { 2 - 3 } & Laki-laki & Perempuan & \\
\hline $0-4$ & 47266 & 44335 & 91601 \\
\hline $5-9$ & 45766 & 42403 & 88169 \\
\hline $10-14$ & 47616 & 44585 & 92201 \\
\hline $15-19$ & 44485 & 40419 & 84904 \\
\hline $20-24$ & 36119 & 34873 & 70992 \\
\hline $25-29$ & 37317 & 37134 & 74451 \\
\hline $30-34$ & 38013 & 38440 & 76453 \\
\hline $35-39$ & 38846 & 39577 & 78423 \\
\hline $40-44$ & 39884 & 39450 & 79334 \\
\hline $45-49$ & 35632 & 35921 & 71553 \\
\hline
\end{tabular}

\begin{tabular}{|c|c|c|c|}
\hline $50-54$ & 31891 & 31861 & 63752 \\
\hline $55-59$ & 26525 & 27461 & 53986 \\
\hline $60-64$ & 21860 & 21508 & 43368 \\
\hline $65+$ & 39355 & 46857 & 86212 \\
\hline Jumlah & $\mathbf{5 3 0 5 7 5}$ & $\mathbf{5 2 4} \mathbf{8 2 4}$ & $\mathbf{1 ~ 0 5 5 ~ 3 9 9}$ \\
\hline
\end{tabular}

Sumber : Data BPS Kabupaten Kuningan

Tabel diatas menujukan bahwa jumlah penduduk berdasarkan umur di Kabupaten Kuningan paling tinggi pada umur 10-14 tahun. Sedangkan kelompok umur terkecil berada pada kelompok umur 60-40 tahun. Penduduk Kabupaten Kuningan juga didominasi kelompok umur produktif yairu berusia 15-65 tahun. Banyaknya penduduk usia produktif dapat dilihat juga dari jenis pekerjaan yang digeluti. Tabel berikut memperlihatkan jenis pekerjaan penduduk di Kabuapten Kuningan sebagai berikut:

\section{Tabel 4}

Jumlah Penduduk Berdasarkan Pekerjaan pekerjaan

\begin{tabular}{|c|c|c|c|}
\hline No. & Pekerjaan & Jumlah & $\begin{array}{c}\text { Prsentase } \\
(\%)\end{array}$ \\
\hline 1 & $\begin{array}{c}\text { Sekotor } \\
\text { pertanian }\end{array}$ & $\begin{array}{c}121.85 \\
4\end{array}$ & 27,97 \\
\hline 2 & Industri & 30.068 & 6,90 \\
\hline 3 & Perdagangan & $\begin{array}{c}150.25 \\
7\end{array}$ & 34,49 \\
\hline 4 & Jasa & 65.464 & 15,02 \\
\hline 5 & Lainnya & 68.069 & 15,62 \\
\hline & Total & $\begin{array}{c}435.71 \\
1\end{array}$ & 100,00 \\
\hline
\end{tabular}

Sumber : Pusdalisbang.JABARProv.Go.id

Tabel 4 memeprlihatkan bahwa jenis pekerjaan penduduk Kabupaten Kuningan lebih banyak disektor perdagangan. Hal ini menunjukkan bahwa penduduk Kabupaten Kuningan lebih banyak yang bekerja disektor perdagangan. Perdagangan yang dilakukan oleh penduduk Kabupaten Kuningan tidak hanya dilakukan tetapi juga diluar Kabupaten Kuningan. Kondisi ini menunjukkan bahwa penduduk Kabupaten Kuningan dikenal sebagai penduduk yang suka merantau untuk berdagang. 
Prosiding Penelitian $\&$ Pengabdian Kepada Masyarakat e ISSN : 2581-1126

p ISSN : 2442-448X
Vol 6, No: 2
Hal: $123-180$
Juli 2019

\section{Faktor Penyebab Kekerasan terhadap Anak}

Kekerasan terhadap anak di Kabupaten Kuningan cukup tinggi, walaupun secara data tidak ada data yang pasti berapa banyak tindak kekerasan yang terjadi. Hal ini dikarenakan tidak semua kekerasan terhadap anak dilaporkan ke pihak yang berwajib. Kondisi ini disebabkan karena:

1. Kekerasan terhadap anak itu merupakan suatu kebiasaan yang sudah dianggap "budaya". Dengan demikian kekerasan terhadap anak. Contoh kekerasan ini adalah memukul untuk mendisiplinkan.

2. Kekerasan terhadap anak merupakan suatu aib bagi keluarga maupun masyarakat. Kasus-kasus kekerasan terhadap anak dianggap akan membawa aib bagi keluarag atauapun masyarakat jika diketahuo oleh masyarakat umum.

3. Belum terintegrasinya data dari setiap instansi yang menrima laporan kekerasan terhadap anak. Dengan demikian data yang ada dari setiap instansi tidak sama.

Faktor-faktor tersebut yang menyebabkan banyaknya kekerasan terhadap anak jranga yang dilaporkan. Data dari kepolisian memperlihatkan bahwa laporan kekerasan setiap tahun di Kabupaten Kuningan 40 sampai 60 kasus. Dengan demikian tidak akuratnya data yang ada. Akan tetapi terlepas dari tidak adanya data kekerasan terhadap anak ada beberapa faktor yang menyebabkan terjadinya kekerasan terhadap anak. Secara garis besar faktor yang menyebabkan terjadinya kekerasan terhadap anak terbagi atas faktor internal dan faktor eksternal.

a. Faktor Internal

Factor internal yang berkaitan dengan kekerasan terhadap anak adalah faktor keluarga. Faktor keluarga berhubungan dengan ekonomi keluarga dan kondisi keluarga. Keluarga dengan ekonomi kerkaitan dengan penemuhan kebutuhan keluarga. Di Kabupaten Kuningan banyak keluarga yang pergi merantau keluar daerah. Dengan kondisi ini anak-anak ditinggalkan baik itu dengan ayah/ibu maupun dengan anggota keluarga lainnya. Kurangnya perhatian terhadap anak menyebabkan anak menjadi korban kekerasan. Anak korban kekerasan pun pada dasarnya dilakukan oleh orangorang terdekat dengan anak atau keluarga.
Kasus kekerasan yang terjadi tersebut menunjukkan bahwa kekerasan yang terjadi tersebut bersifat personal. Ini berarti bahwa kekerasan terhadap anak terjadi karena adanya pelaku kekerasan.

Selain ekonomi, faktor keharmonisana keluarga juga menjadi faktor terjadinya kekerasan terhadap anak. Keluarga yang tidak harmonis cenderung terjadi kekerasan terhadap anak baik dilakukan oleh orang tua maupun saudara. Orang tua yang tidak harmonis cenderung bersikap tidak peduli dengan anak-anaknya. Orang tua yang tidak harmonis akan sibuk dengan permasalahan yang dihadapinya. Dengan demikian orang tua menjadi lalai dengan perkembangan dan pergaulan anak-anaknya. Anak-anak yang butuh perhatian dan perlindungan selanjutnya mencari kegiatan diluar rumah. Dengan demikian anak menjadi rentan untuk menjadi korban kekerasan. Struktur yang tidak mendukung kehidupan yang harmonis ini menjadikan terjadinya tindak kekerasan terhadap anak. Keluarga yang tidak harmonis menunjukkan bahwa struktur keluarga tersebut terganggu yang selanjutnya mendorong terjadinya kasus kekerasan terhadap anak.

\section{b. Faktor Eksternal}

Faktor eksternal adalah faktor yang berasal dari luar keluarga. Faktor eksternal yang berhubungan dengan lingkungan pergaulan dan perkembangan teknologi. Kekerasan terhadap anak yang disebabkan oleh lingkungan sering terjadi di lingkungan sekolah. Saling ejek diantara para siswa menjadi awal terjadinya kekerasan anak. Bullying merupakan bentuk kekerasan yang diawali dari saling ejek diantar siswa. Bullying sangat sering terjadi di institusi pendidikan dari jenjang sekolah dasar sampai sekolah tingkat atas. Bullying terjadi karena adanya perasaan senoritas atau superior pelaku terhadap korbannya. Dengan demikian perilaku bullying pada umumnya dilakukan oleh siswa senior terhadap siswa yuniornya.

Kekerasan terhadap anak yang disebabkan oleh faktor lingkungan lainnya adalah tawuran pelajar. Tawuran antarsekolah di Kabupaten Kuningan sebenarnya tidak sering terjadi. Akan tetapi tawuran antarsekolah juga terjadi. Tawuran seringkali terjadi karena hal-hal yang sepele. Bahkan sering juga terjadi kasus tawuran karena diturunkan oleh kakak kelasnya ke adik- 
Prosiding Penelitian

$\&$ Pengabdian

Kepada Masyarakat

e ISSN : 2581-1126

p ISSN : 2442-448X
Vol 6, No: 2

Hal: $123-180$
Juli 2019 adikinya. Kasus tawuran yang diwariskan ini hanya didasarkan pada kebanggan semu terhadap sekolah masing-masing. Jadi dengan demikian tawuran yang dilakukan hanya untuk kebanggaan terhadap masa lalu.

Faktor eksternal lainnya yang dapat menyebabkan terjadinya tindak kekerasan adalah teknologi. Media sosial dan berbagai game kekerasan mendorong anak-anak untuk mempraktikkanya dengan teman-temannya. Rasa ingin tahu yang sangat besar dalam diri anak-anak mendorong anak-anak untuk mencoba meniru apa yang dilihatnya. Demikian juga dengan mudahnya anak-anak untuk mengakses media sosial setiap saat anak-anak dapat membuka adegan-adegan yang berbau kekerasan. Dengan demikian anak-anak menjadi terbiasa dengan tindak kekerasan. Akibatnya seringkali kasus kekerasan terjadi karena kebiasaan.

Ditinjau dari faktor eksternal juga terlihat bahwa kekerasan terhadap anak yang terjadi di Kabupaten Kuningan bersifat personal dan struktural. Kekerasan yang bersifat personal lebih kepada kekerasan yang terjadi secara langsung. Kasus bullying yang terjadi memperlihatklan bahwa kekerasan yang terjadi tersebut bersifat personal. Sementara itu kekerasan yang bersifat struktur terjadi karena semakin berkurangnya kontrol sosial yang dilakukan oleh masyarakat. Banyaknya tontonan dalam games yang dapat diakses oleh anak-anak menjadikan perilaku lekat dengan kekerasan.

\section{Pelayanan bagi Anak Korban Kekerasan}

Anak korban kekerasan harus mendapatkan pelayanan social untuk menyembuhkan trauma yang dialaminya. Pelayanan yang diberikan bagi anak korban kekerasan diberikan oleh berbagai instasi tergantung kepada tujuan dari pelayanan yang diberikan. Akan tetapi sebelum pelayanan bagi anak korban kekerasan diberikan ada baiknya dilihat terlebih dahulu kebijakan yang memayungi pelayanan yang diberikan.

Kebijakan dalam penanganan anak korban kekerasan sebenarnya sudah ada baik yang bersifat nasional seperti undangundang maupun yang diterbitkan oleh masing-masing daerah. Di Kabupaten Kuningan juga menunjukkan beberapa kebijakan dalam pencegahan kekerasan terhadap anak yang bertujuan untuk melindungi anak-anak. Kebijakan yang berkaitan dengan pencegahan kekerasan terhadap anak adalah:

1. Undang-Undang Nomor 35 Tahun 2014 tentang Perubahan Atas Undang-Undang Nomor 23 Tahun 2002 tentang Perlindungan Anak, Pasal 1 Ayat (2) bahwa Perlindungan Anak adalah segala kegiatan untuk menjamin dan melindungi Anak dan hak-haknya agar dapat hidup, tumbuh, berkembang, dan berpartisipasi secara optimal sesuai dengan harkat dan martabat dan martabat kemanusiaan, serta mendapat perlindungan dari kekerasan dan diskriminasi.

2. Peraturan Daerah Kabupaten Kuningan Nomor 15 Tahun 2013 tentang Penyelenggaraan Perlindungan Anak. Ketentuan Umum Pasal 1 Ayat (6) menyatakan bahwa Penyelenggaraan Perlindungan Anak adalah serangkaian kegiatan yang dilakukan oleh Pemerintah Daerah, masyarakat, dan orang tua yang ditujukan untuk mencegah, mengurangi resiko, dan menangani korban tindakan kekerasan, eksploitasi, perlakuan salah, dan penelantaran terhadap anak. Ayat (7) Hak anak adalah bagian dari hak asasi manusia yang wajib dijamin, dilindungi, dan dipenuhi oleh orang tua, keluarga, masyarakat, pemerintah, dan negara.

Kebijakan perlindungan terhadap anak di Kabupaten Kuningan tidak hanya berupa undagng-undang yang bersifat nasional, tetapi juga peraturan yang lebih bersifat khusus untuk Kabupaten Kuningan. Bahkan dalam kebijkan yang dikeluarkan oleh Pemerintah Kabupaten Kuningan sudah tertera keterlibatan pihak yang harus melindungi anak dari kekerasan. Pihak tersebut harus melibatkan pemerintah, masyarakat dan keluarga. Berdasarkan kebijakan tersebut terlihat bahwa harus ada koordinasi dan kolaborasi antarpihak dalam melindungan anak dari tindakan kekerasan.

Berdasarkan kebijakan yang berupa undang-undang dan peraturan pemerintah yang ada selanjutnya diturunkan lagi kedalam peraturan yang lebih aplikatif dalam pelaksanaanya. Berikut peraturan bupati dan program yang dibuat oleh Pemerintah Kabupaten Kuningan dalam perlindungan terhadap anak 
Prosiding Penelitian

$\&$ Pengabdian

Kepada Masyarakat

e ISSN : 2581-1126

p ISSN : 2442-448X

Vol 6, No: 2

Hal: $123-180$

Juli 2019

1. Peraturan Bupati Kuningan Nomor 40 Tahun 2015 tentang Kebijakan Pengembangan Kabupaten Layak Anak (KLA) di Kabupaten Kuningan. Pasal 1 Ayat (11), Kabupaten Layak Anak selanjutnya disingkat KLA adalah sistem pembangunan suatu wilayah administrasi yang mengintegrasikan komitmen dan sumber daya pemerintah, masyarakat dan dunia usaha yang terencana secara menyeluruh dan berkelanjutan dalam kebijakan program kegiatan untuk menjamin terpenuhinya hak anak. Pada Ayat (10) dinyatakan bahwa pengertian layak adalah kondisi fisik dan non fisik suatu wilayah dimana aspek-aspek kehidupannya memenuhi unsur-unsur yang diatur dalam Konvensi Hak Anak dan/atau Undang-Undang Perlindungan Anak

2. Sekolah ramah anak.

Program sekolah ramah anak merupakan salah satu wujud komitmen pemerintah untuk mendukung Kabupaten Kuningan menuju Kabupaten Layak Anak (KLA). Dalam realisasinya secara teknis, pemerintah dalam hal ini Dinas Sosial telah bersinergi dengan Dinas Pendidikan untuk merealisasikan program ramah anak. Perspektif sekolah ramah anak merupakan program nasional, dimana salah satu perangkat stakeholder yang mendukung realisasinya adalah dari tingkat Pemerintah Provinsi dalam rangka mewujudkan Kabupaten/Kota menjadi kawasan yang ramah anak.

\section{Pelayanan Sosial bagi Anak Korban Kekerasan}

Akan yang mengalami kekerasan cenderung untuk mendapatkan trauma selam hidupnya. Dalam mengatasi dampak dari kekerasan yang dialami oleh anak ini semua pihak yang concern terhadap perkembangan anak harus memberikan pelayanan. Tujuan dari pelayanan tersebut adalah untuk mengembalikan kondisi anak seperti semula serta menghilangkan dampak yang kemungkinan terjadi dimasa yang akan datang. Berdasarkan kebijakan yang ada di Kabupaten Kuningan pelayanan terhadap anak yang mendapatkan kekerasan melibatkan berbagai pihak baik itu pemerintah, keluarga, sekolah, maupun masyarakat. Berdasarkan kebijakan tersebut terlihat bahwa harus ada koordinasi dan kolaborasi antarpihak dalam melindungan anak dari tindakan kekerasan.

Pelayanan social bagi anak yang mengalami kekerasan mengacu kepada dimensi pelayanan sosial dari Kahn (1973) yaitu:

1. Program-program mengacu kepada kegiatan-kegiatan baik yang dilakukan oleh pemerintah, swasta, maupun masyarakat

2. Tanpa mempertimbangkan kriteria pasar mengacu kepada pelayanan tersebut tidak mempertimbangkan apakah penerimanya mampu membayar atau tidak

3. Individu, keluarga, kelompok, dan masyarakat mengacu kepada sasaran dari suatu program atau kegiatan yang dilakukan

4. Kesejahteraan mengacu pada tujuan yang ingin dicapai oleh program atau kegiatan terhadap sasarannya.

Berdasarkan dimensi pelayanan sosial dari Kahn, keterlibatan berbagai pihak menjadi hal yang harus dilaksanakan dalam pelayanan sosial. Hal ini juga terjadi di Kabupaten Kuningan dalam memberikan pelayanan bagi anak yang mengalami kekerasan. Pihak yang terlibat dalam pemberian pelayanan social bagi anak yang mengalami kekerasan di Kabupaten Kuningan melibatkan pemerintah, keluarga, sekolah dan masyarakat. Pelayanan bagi anak korban kekerasan tidak melihat kondisi dari anak dan keluarganya tersebut. Semua anak yang mengalami kekerasan akan mendapatkan pelayanan yang sama. Demikian juga sasaran pelayanan sosial bagi anak korban kekerasan meliputi individu anak itu sendiri, keluarganya.

Pelayanan sosial bagi anak yang mengalami kekerasan dari pihak pemerintah di Kabupaten Kuningan diberikan oleh dinas sosial, dinas kesehatan, P2TP2A, kepolisian, kejkasaan, dan kehakiman. Sementara pihak sekolah berkaitan dengan dinas pendidikan dan kebudayaan. Pihak keluarga korban dan dari pihak masyarakat adalah LSM Rampag Polah.

\section{a. Dinas Sosial Kabupaten Kuningan}

Dinas Sosial merupakan dinas yang paling kompeten dalam melindungi anak dari semua tindakan kekerasan. Dinas sosial berperan penting dalam penanganan anak korban kekerasan. Tugas pokok dan fungsi dari Dinas Sosial ini adalah melindungi setiap 
Prosiding Penelitian $\&$ Pengabdian Kepada Masyarakat e ISSN : 2581-1126

p ISSN : 2442-448X
Vol 6, No: 2

Hal: $123-180$
Juli 2019 hak yang dimiliki oleh anak. Dengan tugas pokok dan fungsi inilah Dinas Sosial harus mampu berperan tidak hanya menangani kekerasan terhadap anak. Lebih penting lagi Dinas Sosial harus mampu untuk mencegah terjadinya kekerasan terhadap anak.

Pelayanan yang diberikan oleh Dinas Sosial Kabupaten Kuningan dapat bersifat langsung maupun rujukan dari lain. Pada dasarnya anak korban kekerasan yang ditangani oleh Dinas Sosial akan diassess untuk melihat trauma yang dialaminya. Hasil assessment yang dilakukan menentukan treatment yang diberikan. Jika ada luka fisik, maka Dinas Sosial akan menghubungi Dinas Kesehatan untuk mendapatkan pelayanan. Demikian juga jika kasus kekerasan ini dijinkan oleh keluarganya untuk ditempuh jalur hukum, maka Dinas Sosial akan menghubungi pihak kepolisian.

Di bawah otoritas Dinas Sosial, Kabupaten Kuningan telah membentuk tim P2TP2A dengan mitra kerja diantaranya Kepolisian dan bidang Perlindungan Perempuan dan Anak, sebagai tugas pokok dan fungsi untuk menanggulangi kekerasan terhadap anak, baik fisik maupun seksual. Selain itu dalam penanganan kekersana terhadap anak, Dinas Sosial Kabupaten Kuningan juga bekerjasama dengan tim Pekerja Sosial (Peksos). Dalam tugas pokok dan fungsi penanganan anak korban kekerasan, Dinas Sosial Kabupaten Kuningan berkoordinasi dengan SKPD terkait. Di Kabupaten Kuningan SKPD telah bersinergi dalam keanggotan P2TP2A yaitu di dalamnya beranggotakan Dinas Sosial, Dinas Kesehatan, Kepolisian, dan Dinas Pendidikan dan Kebudayaan. Masing-masing perangkat pemerintah tersebut melakukan kinerja dan fungsi sesuai tugasnya.

Pelayanan yang diberikan oleh Dinas Sosial Kabupaten Kuningann selain memberikan rujukan jika ada trauma yang dialami oleh anak korban kekerasan juga melakukan pendampingan. Pendampingan ini diberikan ketika anak tersebut dirujuk kepihak lain. Bahkan jika kasus kekerasan terhadap anak ini harus masuk kepengadilan, maka Dinas Sosial khususnya pekerja social harus memberikan rekomendasi bahwa kasus tersebut dapat ditangani oleh pengadilan.

\section{b. Kepolisian Kuningan}

Pihak kepolisian merupakan pihak yang paling berfungsi untuk menekan kekerasan terhadap anak. Dalam menjalankan tugas dan fungsinya pihak kepolisian tidak dapat bekerja sendiri. Pihak kepolisian tidak dapat bertindak tanpa adanya laporan terjadinya tindak kekerasan. Akan tetapi pihak kepolisian resort Kuningan telah melakukan koordinasi dengan pihak lain seperti P2TP2A, Dinas Sosial, Dinas Pendidikan. Selain itu kepolisian Resort Kuningan melakukan sosialisasi kekerasan kepada aparat desa, aparat kecamatan dan insstansi lainnya yang berkaitan dengan anak. Sosialisasi yang dilakukan oleh pihak Kepolisian Resort Kuningan bekerjasama dengan P2TP2A. Sosialisasi mengenai pencegahan tindak kekerasan terhadap anak yang dilakukan oleh pihak Kepolisian Resort Kuningan dilakukan 2 sampai 4 kali dalam setahun

Kepolisian Resort Kuningan dalam tugas dan fungsinya lebih banyak bersifat kuratif. Kepolisian Resort Kuningan menunggu laporan terjadinya tindak kekerasan terhadap anak. Penanganan yang dilakukan oleh pihak Kepolisian Resort Kuningan lebih banyak difokuskan kepada pelaku. Penanganan terhadap pelaku tindak kekerasan terhadap anak yang dilakukan oleh pihak Keplisian Resort Kuningan lebih menitikberatkan kepada upaya rehabilitasi. Hal ini dimaksudkan untuk merubah perilaku pelaku dan mendorong munculnya kesadaran dari diri pelaku mengenai salahnya tindak kekerasan terhadap anak. Alasan lainnya adalah untuk menekan timbulnya perilaku yang lebih agresif dari pelaku jika dihukum penjara. Kepolisian Resort Kuningan bekerja sama dengan Dinas Sosial Kabupaten Kuningan dalam proses rehabilitasi terhadap pelaku tindak kekerasan terhadap anak. Koordinasi juga dilakukan dengan Dinas Kesehatan untuk melakukan visum terhadap anak korban kekerasan maupun tindakan lainnya. Koordinasi lainnya dilakukan dengan Dinas Pendidikan Kabupaten Kuningan dalam penanganan maupun pencegahan kekerasan anak di sekolah.

\section{c. Dinas Pendidikan dan Kebudayaan}

Dinas Pendidikan dan Kebudayaan merupakan instansi yang berdiri paling depan dalam pencegahan terhadap kekerasan yang dialami oleh anak. Hal ini dikarenakan Dinas Pendidikan dan Kebudayaan berhubungan langsung dengan anak-anak. Dinas 
Prosiding Penelitian $\&$ Pengabdian Kepada Masyarakat e ISSN : 2581-1126

p ISSN : 2442-448X
Vol 6, No: 2
Hal: $123-180$
Juli 2019
Pendidikan dan Kebudayaan Kabupaten Kuningan telah melakukan berbagai tindakan preventif melalui upaya-upaya sosialisasi ke sekolah-sekolah maupun pada saat pertemuan dengan orang tua murid dalam rangka mencegah terjadinya kasus-kasus kekerasan terhadap anak di lingkungan sekolah.

Secara regulasi, sosialisasi pencegahan kekerasan terhadap anak yang dilakukan oleh Dinas Pendidikan dan Kebudayaan Kabupaten Kuningan berkoordinasi dengan stakeholder terkait termasuk salah satunya dengan Kepolisian Resort Kuningan. Kegiatan sosialisasi yang dilakukan oleh Dinas Pendidikan dan Kebudayaan dengan melibatkan pihak Kepolisian Resort Kuningan juga melibatkan para guru Bimbingan Konseling (BK). Sosialisasi yang dilakukan oleh Dinas Pendidikan dan Kebudayaan sebagai upaya untuk mengantisipasi kekerasan anak di lingkungan sekolah. Hal ini perlu dilakukan karena di Kabupaten Kuningan tindak kekerasan terhadap anak lebih banyak terjadi dilingkungan sekolah. Kasus bullying dan tawuran antarpelajar sebagai contoh banyaknya tindak kekerasan yang terjadi di lingkungan sekolah. Osisalisasi ini dapat dilakukan secara langsung maupun secara online.

\section{d. Dinas Kesehatan}

Dinas Kesehatan merupakn dinas yang paling banyak melakukan koordinasi dengan instansi lain dalam menangani kekerasan terhadap anak. Hal ini dikarenakan hampir semua tindak kekerasan terhadap anak memerlukan pemeriksaan fisik. Pemeriksaan fisik tersebut mulai dari visum untuk keberlanjutan kasus kekerasan di kepolisian sampai surat keterangan bagi instansi lainnya. Secara garis besar Dinas Kesehatan Kabupaten Kuningan dalam penanganan anak korban kekerasan yaitu dengan memberikan pelayanan penanganan dan pelayanan kesehatan korban. Selain pelayanan kesehatan fisik, Dinas Kesehatan juga memberikan pelayana khsuus kepada anak korban kekerasan seksual yang mengalami kehamilan. Dinas Kesehatan memberikan fasilitas khusus terhadap anak korban kekerasan seksual yang hamil. Pelayana tersebut diberikan selama proses kehamilan. Dinas Kesehatan juga mencoba memberikan dan memfasilitasi korban untuk memperoleh bantuan dari pemerintah yaitu berupa bantuan Jampersal. Dengan jampersal ini diharapkan semua biaya persalinan telah dibayarkan sehingga pihak keluarga dan korban tidak perlu lagi untuk mebayar biaya persalinan.

Pelayanan yang diberikan oleh Dinas Kesehatan Kabupaten Kuningan bagi anak korban kekerasan seara teknis dilakukan oleh Rumah Sakit Umum Daerah (RSUD). Pelayanan yang diberikan oleh RSUD terhadap anak korban kekerasan berupa pemeriksaan fisik korban, pelayanan visum yang diberikan oleh tim visum RSUD. Hasil visum ini dapat digunakan oleh pihak kepolisian untuk menjerat pelaku dan menyeretnya ke pengadilan. Secara spesifik dalam penanganan kekerasan terhadap anak Dinas Kesehatan berkoordinasi dengan Kepolisian, Dinas Sosial, Pekerja Sosial, termasuk Gerakan Organisasi Wanita (GOW). Koordinasi Dinas Kesehatan dengan instansi tersebut dalam rangka penangan terhadap anak korban kekerasan.

\section{e. LSM Rampak Polah}

Penanganan terhadap anak korban kekerasan bukan saja kewajiban pemerintah. Semua pihak harus terlibat termasuk masyarakat lewat lembaga swadaya masyarakat (LSM). Keterlibatan LSM dalam penanganan kekerasan terhadap anak menjadi krusial karena LSM berasal dari masyarakat sehingga pelayanan yang diberikan juga lebih mudah. Di Kabuppaten Kuningan LSM yang peduli terhadap anak korban kekerasan dan kekerasan terhadap anak salah satunya adalah LSM Rampak Polah.

Konsep penanganan kasus yang dilakukan LSM Rampak Polah adalah dari 0 kasus ke 0 kasus. Ini berarti pelayanan yang diberikan oleh Rampak Polah harus menjadikan kasus tersebut terselesaikan. LSM Rampak Polah memberikan pendampingan bagi anak korban kekerasan jika kasus tersebut harus dirujuk ke Dinas terkait seperti Pemberdayaan Perempuan, Dinas Kesehatan. Dinas Sosial, dan Kepolisian maupun BPJS jika ada pembiayaan yang harus ditanggung oleh anak korban kekerasan atau keluarganya. Pelayanan yang diberikan oleh ISM Rampak Polah adakalanya tidak dilaporkan dan berkoordinasi dengan pihak pemerintah atau dinas tertentu. Alasan tidak dilaporkannya kasus kekerasan terhada anak adalah untuk membangun kepercayaan 
Prosiding Penelitian $\&$ Pengabdian Kepada Masyarakat e ISSN : 2581-1126

p ISSN : 2442-448X
Vol 6, No: 2
Hal: $123-180$
Juli 2019 antara pihal LSM Rampak Polah dengan anak korban kekerasan dan keluarganya. Selain itu kasus yang dilaporkan kepada LSM Rampak Polah juga menurut keluarganya tidak berat jadi tidak perlu dilaporkan kepada pemerintah.

Pelayanan lainnya yang bersifat khas yang diberikan oleh LSM Rampak Polah adalah pemberdayaan terhadap korban kekerasan, khususnya perempuan. Tujuan dari pelayanan ini adalah agar perempuan korban kekerasan setelah kasusunya dapat diselesaikan dapat hidup mandiri tidak tergantung kepada laki-laki. Pelayaan pemberdayaan perempuan yang dilakukan oleh LSM Rampak Polah bekerja sama denganm Dinas Pemberdayaan Perempuan Kabupaten Kuningan.

\section{Kendala dalam Pelayanan bagi Anak Korban Kekerasan}

Pelayanan yang diberikan bagi anak korban kekerasan harus melibatkan banyak institusi. Hal ini dikarenakan dampak dari kekerasan terhadap anak yang luas. Akan tetapi dalam praktiknya pelibatan banyaknya institusi menemui berbagai kendala diantaranya:

1. Banyaknya institusi yang terlibat menjadikan sulit mellakukan koordinasi diantara insitutis yang ada. Hal ini dikarenakan setiap institusi mempunyai standar operasional masing-masing. Akibatnya seringkali menjadikan pelayanan yang diberikan menjadi leboih berbelit dan memerlukan waktu yang lama.

2. Dana untuk pelayanan bagi anak korban kekerasan yang masih sedikit dan tidak khusus. Dana yang digunakan untuk pelayanan bagi anak korban kekerasan masih bercampur dengan dana lainnya. Denagn demikian seringkali korban yang memerlukan pelayanan harus membayar sendiri.

3. Masih banyaknya kasus kekerasan terhadap anak yang tidak dilaporkan kepihak terkait. Akibatnya anak korban kekerasan tidak mendapatkan pelayanan yang diperlukan.

\section{Kesimpulan}

1. Kekerasan terhadap anak terjadi disebabkan faktor yang kompelks dan terjadi massif dalam masyarakat. Hal ini dikarenakan kekerasan terhadap anak seringkali diabaikan dan terlindung oleh budaya.

2. Belum adanya model yang komprehensif dalam memberikan pelayanan kepada anak korban kekerasan sehingga setiap institusi memberikan pelayanan sendiri.

3. Kurang pahamnya masyarakat berkaitan dengan kekerasan terhadap anak sehingga masih banyak kasus kekerasan yang tidak dilaporkan sehingga anak korban kekerasan tidak mendapatkan pelayanan yang semestinya.

\section{Saran}

1. Perlunya peningkatan koordinasi antarinstitusi agar melayanan yang diberikan lebih masksimal.

2. Perlu adanya keterlibatan masyarakat yang lebih agar tindak kekerana terhadap anak dapat ditekan. Keterlibatan masyarakat dapat dilakukan dengan membentuk kelompok masyarakat yang peduli terhadap penanggulangan kekerasan terhadap anak.

\section{DAFTAR PUSTAKA}

Buku

Apsari, Nurliana Cipta, 2015, Hak Anak, Bandung, Widya Padjadjaran

Galtung, Johan, 1990, Culture Violence, Journal of Peace Research (online), Vol. 27 No. 3 halaman 291-305 dalam Linda Dwi Eriyanti “Pemikiran Johan Galtung tentang Kekerasan dalam Perspektif Feminisme" Jurnal; Hubungan Internasional Vol 6 No. 1 tahun 2017

Kementrian Sosial, Kementrian Pemberdayaan Perempuan dan Perlindungan Anak, Badan Peremcanaan Pembangunan Nasional, Badan Pusat Statistik, UNICEF Indonesia, 2013, Survey Kekerasan terhadap Anak Indonesia Tahun 2013, Laporan Penelitian

Karen K. Kirst-Ashman, 2010, Introduction to Social Work \& Social Welfare: Critical Thinking Perspectives, Third Edition, New York, NY Brooks/Cole.

Mulyana, Nandang, Risna Resnawaty, Gigin Basar, 2017, Penanganan Anak Korban Kekerasan, Bandung, Indonesia, Bandung, Widya Padjadjaran 


\begin{tabular}{|c|c|c|c|c|}
\hline $\begin{array}{c}\text { Prosiding Penelitian } \\
\text { \& Pengabdian } \\
\text { Kepada Masyarakat }\end{array}$ & e ISSN : 2581-1126 & Vol 6, No: 2 & Hal: $123-180$ & Juli 2019 \\
\hline
\end{tabular}

Mulyana, Nandang, Hetty Krisnani, 2016, Intervensi terhadap Remaja Korban Kriminal, Bandung, Widya Padjadjaran

Mulyana, Nandang, Hetty Krisnani, 2016, Intervensi bagi Remaja Pelaku Kriminal, Bandung, Widya Padjadjaran

Pert, Crishtoper G, 2004, Social Work Children And Their Families pragmatic Foundation. Oxford University Press.

Spicker, Paul, 1995, Social Policy : Theory and Parctice, Publishing wuth Purpose

Suharto, Edi, 2008, Kebijakan Sosial sebagai Kebijakan Publik, Bandung, CV Alfabeta

Suharto, Edi, 2005, Analisis Kebijakan Publik, Panduan Praktis Mengkaji Masalah dan Kebijakan Sosial, Bandung; CV Alfabeta

Suharto, Edi, 2006, Kebjakan Sosial, makalah seminar, Bandung

United Nations Convention on the Rights of the Child, Tahun 1989

Wibhawa, Budhi, Nandang Mulyana, 2016, Masalah Sosial Kontemporer, Bandung, Indonesia, Niaga Muda

Zastrow, Charles and Karen K. Kirst-Ashman. (2007) Understanding Human Behavior and Social Environment. 7th edition. Thomson Brooks/Cole, a part of The Thomson Corporation.

\section{Peraturan}

Republik Indonesia, Undang-Undang Republik Indonesia Nomor 35 tahun 2014 tentang Perubahan Atas Undangundang Republik Indonesia Nomor 23 Tahun 2002 Tentang Perlindungan Anak.

Republik Indonesia, Undang-Undang Republik Indonesia Nomor 11 Tahun 2012 Tentang Sistem Peradilan Pidana Anak.

Republik Indonesia, Undang-undang Republik Indonesia Nomor 23 Tahun 2002 Tentang Perlindungan Anak.
Republik Indonesia, Undang-Undang Republik Indonesia Nomor 39 Tahun 1999 Tentang Hak Asasi Manusia.

Peraturan Daerah Kabupaten Kuningan Nomor 15 Tahun 2013 tentang Penyelenggaraan Perlindungan Anak, Kuningan

Peraturan Bupati Kuningan Nomor 40 Tahun 2015 tentang Kebijakan Pengembangan Kabupaten Layak Anak (KLA) di Kabupaten Kuningan

\section{Publikasi Elektronik}

Wikipedia Bahasa Indonesia, ensiklopedia bebas. Terakhir diunggah pada 07:09, 7 Oktober 2010. Diakses tanggal 23 Januari 2011

Mentri Sosial, Kekerasan pada Anak, apalagi Kejahatan Seksual harus dihentikan, www. Kompas.com, diakses tanggal 20 Mei 2016.

www. Kompas.com, diakses tanggal 10 Mei 2016.

Komnas PA: 2015 Kekerasan Terttinggi selama Lima Tahun Terakhir, www.news.liputan6 .com diakses 20 Januari 2018

www.friedenspaedagogik.de/content/pdf/275 4 diakses 07 Juni 2017

Children Are The Future, Convention on the Child (Konvensi Hak Anak), www.rightsvoiceofchildren.blogspot.co.i d/2008/06/convention-on-rights-of-childkonvensi.html\#.Wm7lO6inHIU diakses 20 Juni 2017

http://www.friedenspaedagogik.de/content/pd f/2754 diakses 24 Juli 2017

www.kpai.go.id/ diakses 23 Agustus 2017 
